\title{
From concepts to practice: combining different approaches to understand drivers of landscape change
}

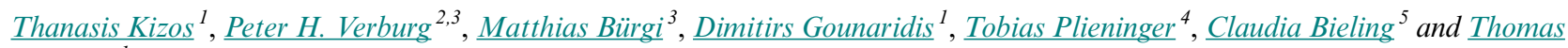 \\ $\underline{\text { Balatsos }}^{1}$
}

\begin{abstract}
Landscape change and its drivers have been the focus of a growing body of literature in the past years. Our objective is to present different approaches to studying and understanding landscape change. We sketch the way in which different approaches and existing conceptual models are related to spatial scales and epistemological aims, and discuss complementarity and a range of applications with five specific research approaches from a Mediterranean landscape, including approaches at national and European levels. These include an analysis of historical landscape change, an investigation of decision-making processes, public awareness raising, evaluation of landscape services, and provision of policy support with data from published and unpublished material. The findings indicate that on the issue of complementarity, some models work better together with others. A major difference observed is the role that conceptual models and related approaches provide to the "voice" of stakeholders and actors of landscape change, sometimes contradicting, but often complementary. An important issue that comes up is a need for a plurality of research approaches and underlying conceptualizations of human-environment interactions, as the approaches represent different lenses for looking at the humanenvironmental system that are all abstractions from the full complexity of how decision-making on land use is conducted.
\end{abstract}

Key Words: driving forces; landscape change; Lesvos

\section{INTRODUCTION}

Landscape change has been the focus of a growing body of literature in the past years (Helfenstein et al. 2014, Plieninger at al. 2015, Qviström and Vicenzotti 2016), paralleled by a continuous increase in the use of the term landscape in studies related to, for example, land use, environmental change, agriculture, and land management. The underlying drivers or causes of landscape changes have been investigated by many different approaches, which has resulted in a diversity of terminologies (Meyfroidt 2015, Van Vliet et al. 2015a, 2015b, Eiter and Potthoff 2016, Plieninger et al. 2016).

Our objective is to present different approaches to studying and understanding landscape change, following the "portfolio approach" of Young et al. (2006); i.e., a pluralistic and inclusive approach to set questions, and choose methods and data. We sketch the way in which different methods are related to spatial scales, epistemological aims, and conceptual models. Subsequently, we determine the complementarity and range of applications. Our intention is to contribute to a clarification and improved structuring of driving forces research and to specify the added value of the diverse methods approaches found in the literature. We attempt to answer three questions in relation to the concept of driving forces: (a) How does the selection of the conceptual model of the driving forces-actors-changerelationship influence the results of a study? (b) How are outcomes mediated by the different spatial scales selected in these methods? (c) Are the different methods for understanding the driving forces of landscape change complementary, or do they deliver contradicting results?
We first review various approaches to identifying the drivers of landscape change. We then relate the conceptual models underlying these methods by using a framework that links several conceptual models of causal chains with research questions and spatial scales. We apply the different approaches to the same landscape to gain insights on the complementarity and suitability of the different approaches for specific questions and scales of analysis.

\section{DRIVERS OF LANDSCAPE CHANGE: TERMINOLOGY AND CONCEPTS}

The analysis of drivers of landscape change is a core field of research in geography, and builds on a long tradition to understand why landscapes change or remain unchanged, and why they evolve faster or slower, and to identify the causal mechanisms of regime shifts (Verburg et al. 2015). More than 25 years ago, Kates et al. (1990) stated that a theory of humanenvironment relationships needs to conceptualize the connections between the driving forces of human-induced change, their mitigating processes and activities, and human behavior and organization. Thus, the system under study includes real-world changes (i.e., land change), human agency (i.e., actors), and influential factors, which have been termed driving forces (Bürgi et al. 2004), keystone processes (Marcucci 2000), or simply drivers (Wood and Handley 2001). The study of these drivers is challenging because they form a complex system of dependencies, interactions, and feedback loops, and they act at several temporal and spatial levels (Fig. 1).

\footnotetext{
${ }^{1}$ Department of Geography, University of the Aegean, ${ }^{2}$ Environmental Geography Group, VU University Amsterdam, ${ }^{3}$ Swiss Federal Research Institute WSL, ${ }^{4}$ Social-Ecological Interactions in Agricultural Systems, University of Kassel and University of Göttingen, Germany, ${ }^{5}$ Institute of Social Sciences in Agriculture, Societal Transition and Agriculture (430b), University of Hohenheim
} 
Fig. 1. Different scales and actors involved in landscape change.

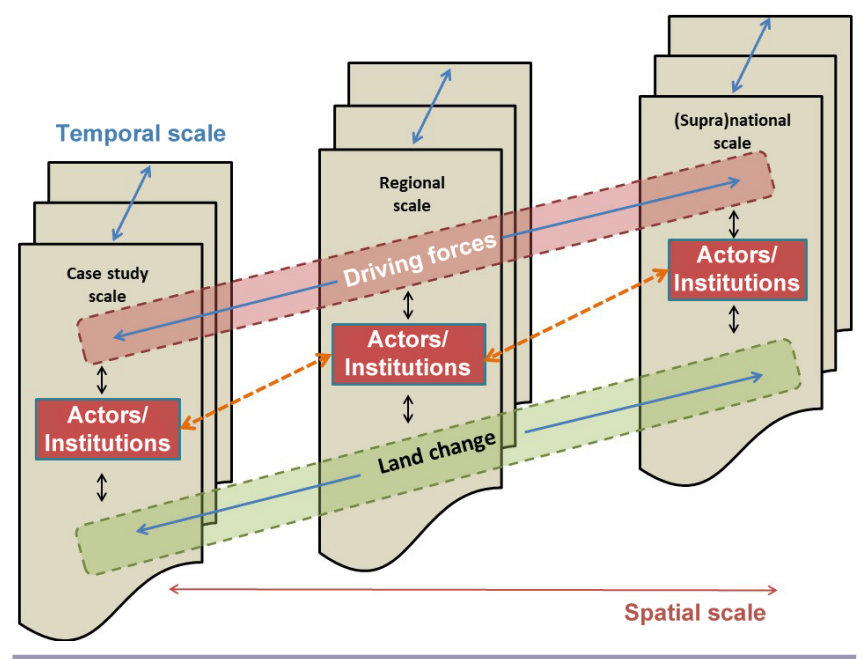

Recent attempts by Meyfroidt (2015) to standardize the use of certain core terms and concepts are a reaction to the confusing diversity in terminology. This diversity, however, might be seen as an expression of a vibrant field that includes diverging epistemological interests, approaches, scales, and fundamental research interests within land change science and landscape research. This opens the field to a wide diversity of studies that relate in one way or another to the concept of driving forces (Eiter and Potthoff 2016).

One attempt to provide an overview of different conceptual representations in land science was presented by Hersperger et al. (2010) (Fig. 2), who distinguish four basic models to represent the relationship of land change (C), driving forces (DF), and actors (A). The first model is the DF-C model (1), in which driving forces are directly related to land change; i.e., the model assumes that driving forces directly cause the observed land change, while actors are not explicitly addressed (unlike in the other three models). The DF-A-C model(2) represents a chain of events from driving forces affecting actors and subsequently actors causing change. By putting the driving forces first, one assumes that they determine the actor's actions that result in change. The DFA-C model (3) sees driving forces and actors in close and reciprocal interaction, which results in landscape changes. Therefore, the interplay of driving forces and actors, including feedbacks, are put at the core of the study. The AC-model (4) puts actors on central stage. Driving forces considered in the first three models are complemented by individual factors, such as knowledge, experiences, and belief systems, all playing a part in the decisionmaking process. The model thus represents the understanding that land change is often the cumulative result of individual agents' decisions.

These four models should not be treated as mutually exclusive but as attempts to provide conceptual frameworks for different applications and scales. Commonly, the more weight that is put on single actors' decisions, the smaller the scale of study will have to be, as larger scale studies inevitably have to include more diverse actors, who are assessed and integrated adequately (Verburg
2014). Relations between the study scale, the approaches chosen, and the role of quantification, data availability, and upscaling therein have recently been discussed by Eiter and Potthoff (2016). We use these four conceptual models in a spatial context, referred to as landscape, link them with specific research approaches, and then illustrate their application in a Mediterranean landscape.

\section{LINKING DRIVING FORCES CONCEPTS WITH RESEARCH AIMS AND SPATIAL SCALES}

Conceptually, landscapes are multilayered, reflect both short- and long-term histories, and are managed by actors who respond to smaller and larger scale policies and incentives. Therefore, landscape research will, by definition, aim to address multiple spatial, temporal, and institutional scales. However, landscape is not only a scale but also includes a management approach that "seeks to provide tools and concepts to achieve joint social, economic, and environmental objectives in landscapes where productive land uses compete with environmental goals" (Plieninger et al. 2015). Landscape can also be a spatial unit of reference for policies and decision-making and an object perceived and valued by different social groups. Such a multiscale and integrative approach is limited by practicalities, such as particular objectives of the research or availability of data, and it raises questions if this multiplicity of usages and meanings can be reconciled under any single research project. This paper is the result of an effort to contextualize a number of different approaches in landscape change research.

In order to spatially contextualize the four models proposed by Hersperger et al. (2010), and to link them to specific research approaches, we tabulated the four conceptual models with four different spatial scales commonly used in landscape change research (Fig. 2): the local-case study level (typically small in extent and related to a specific locality, such as a village, municipality, landscape, or watershed); the small region level (defined for Europe at the administrative boundaries of Nomenclature d'Unités Territoriales Statistiques [NUTS], which correspond roughly to the Prefecture [NUTS III] and Regional[NUTS II] levels) and typically including many landscape types; the national level; and the supranational level (e.g., the European Union).

The upper left corner of Fig. 2 ("case study"/"small region" scales and DF-C, DF-A-C models) contains research that aims at understanding the functioning of the landscape system, and addressing questions such as the following: How has the landscape developed (e.g., via oral histories, local texts, and narratives)? What are the values assigned to these landscapes by its users (e.g., via questionnaires, image elicitation, or public participation geographical information systems (PPGIS) (Fagerholm et al. 2012, Palomo et al. 2013, Scolozzi et al. 2014)? What are the drivers of landscape change (e.g., Bürgi et al. 2015, Lieskovský et al. 2015)? What are specific combinations of driving forces and actors that lead to change (e.g., Bohnet 2008, Bieling et al. 2013, Bürgi et al. 2017)? These approaches tend to span years and decades rather than longer time periods.

Research approaches in the lower left corner of Fig. 2 focus on more detailed actor analyses, including feedback between actors and diversity of behaviors. Here, actors and their role are central, as expressed in the DFA-C and A-C models. The approaches used account for a wide diversity of actors at the local scale, and their motivations, perceptions, and adaptive responses to landscape 
Fig. 2. The four conceptual models of Hesperger et al. (2010), with scale of analysis and research approaches for the case studies of the Gera landscape.

\begin{tabular}{|c|c|c|c|c|c|}
\hline \multirow{2}{*}{$\begin{array}{c}\text { Conceptual } \\
\text { models }\end{array}$} & \multirow[t]{2}{*}{ Study aim } & \multicolumn{3}{|c|}{$\begin{array}{l}\text { Scale of } \\
\text { analysis }\end{array}$} & \multirow[b]{2}{*}{$\begin{array}{c}\text { Supra- } \\
\text { national }\end{array}$} \\
\hline & & $\begin{array}{l}\text { Case } \\
\text { study }\end{array}$ & $\begin{array}{l}\text { Small } \\
\text { region }\end{array}$ & National & \\
\hline $\begin{array}{l}\text { Driving force- } \\
\text { Land change } \\
\text { (DF-C) }\end{array}$ & $\begin{array}{l}\text { - Exploration } \\
\text { - Generation of hypothesis } \\
\text { - Estimation of parameters for theoretical } \\
\text { models }\end{array}$ & \multirow{2}{*}{\multicolumn{2}{|c|}{$\begin{array}{c}\text { Case study analysis of landscape history } \\
\text { and driving factors of past and current } \\
\text { landscape change (Case A) }\end{array}$}} & \multirow{2}{*}{$\begin{array}{c}\text { Synthesis } \\
\text { and meta- } \\
\text { analysis }\end{array}$} & \multirow{2}{*}{$\begin{array}{l}\text { Decision } \\
\text { support for } \\
\text { informed } \\
\text { policy } \\
\text { (Case E) }\end{array}$} \\
\hline $\begin{array}{l}\text { Driving force- } \\
\text { Actor - Land } \\
\text { change } \\
\text { (DF-A-C) }\end{array}$ & $\begin{array}{l}\text { - Understanding causal chain driving forces - } \\
\text { actors-change } \\
\text { - Identifying specific combinations of driving } \\
\text { forces and actors that lead to change }\end{array}$ & & & & \\
\hline $\begin{array}{l}\text { Driving } \\
\text { force/Actor - } \\
\text { Land change } \\
\text { (DFA-C) }\end{array}$ & $\begin{array}{l}\text { - Interactions among actors and drivers of land } \\
\text { change, including feedbacks } \\
\text { - Policy analysis and intervention }\end{array}$ & \multirow{2}{*}{$\begin{array}{l}\text { - Raising awareness } \\
\text { and stewardship } \\
\text { options (Case C) } \\
\text { - Evaluation of } \\
\text { landscape values } \\
\text { (Case D) } \\
\text { - Agent-based } \\
\text { modeling of } \\
\text { landscape change } \\
\text { (Case B) }\end{array}$} & \multirow{2}{*}{$\begin{array}{l}\text { Transdisciplinary } \\
\text { discussions } \\
\text { aimed at } \\
\text { developing } \\
\text { stewardship of } \\
\text { cultural } \\
\text { landscapes }\end{array}$} & & \\
\hline $\begin{array}{l}\text { Actor - Land } \\
\text { change (A-C) }\end{array}$ & $\begin{array}{l}\text { - Actor behavior and decision-making resulting } \\
\text { in land change } \\
\text { - Interactions among actors of land change, } \\
\text { including feedbacks } \\
\text { - Policy analysis and intervention } \\
\text { - Social learning }\end{array}$ & & & & \\
\hline
\end{tabular}

continuity and change, including landscape stewardship and awareness-raising approaches (e.g., Castella et al. 2005, VallésPlanells et al. 2014). Methods include codesign of stewardship options during stakeholder workshops and agent-based models to evaluate alternative landscape futures that represent the diversity and development of agent behavior (Valbuena et al. 2010, van Berkel and Verburg 2014). Here, the barriers and opportunities for action within the studied area are central topics of research.

In the upper right corner of Fig. 2, research refers to larger spatial scales and involves methods and questions that either operate directly at a larger scale or enable the contextualization and synthesis of case studies in this larger scale analysis (e.g., Thapa and Rasul 2006, Gennaio et al. 2009, Willemen et al. 2010, Jepsen et al. 2015, Stürck et al. 2015, Levers et al. 2016, Loran et al. 2016, van Zanten et al. 2016). What are the patterns of historical landscape continuity and change? What approaches can be used for the evaluation of landscape services? Techniques employed include spatial data analysis but also narrative analysis at the level of countries or supranational units. At the same time, this research is aimed at informing decision-making, policy design, and evaluation (e.g., via ex-ante models that evaluate the impact of alternative policies). Often these approaches use simplified conceptual models, put less focus on actor diversity, and strongly simplify actor behavior as a consequence of the scale (Rounsevell et al. 2014). Another approach to address larger scales is by upscaling and contextualizing case studies within the area by meta-analysis of existing case studies to identify what drivers the case studies have in common or how context determines the drivers. Alternatively, upscaling from case studies might be done based on the representativeness of the case study for a larger area (Václavík et al. 2016).

In the lower right corner of Fig. 2, methods that fully account for agency hardly exist at such large scales, in spite of pleas for including agency better in large-scale landscape change assessments (Verburg et al. 2015). At these scales, agency does not necessarily refer to individual agents but may also refer to institutional agents. Therefore, processes of exchange and consultation with institutions involved in landscape policies have often been considered as a way to account for agency at such levels of aggregation. However, the description of agency at this level of analysis is often highly simplified and may be insufficient to capture the behavioral complexity involved (Arneth et al. 2014).

\section{DRIVING FORCES, ACTORS, INSTITUTIONS, AND LANDSCAPE CHANGE: THE CASE OF THE GERA LANDSCAPE}

The case study landscape in this paper is that of the Gera locality, which is located in the southeastern part of Lesvos Island in the northeastern Aegean Sea (Fig. 3). Its climate is Mediterranean, its terrain hilly, and its landscape has consisted of terraced, continuous olive plantations (at roughly 450-550 m altitude), and 
forested areas (of pine and oaks, from 450 to $500 \mathrm{~m}$ altitude upwards) since the end of the 18th century. Olive plantations are characterized by traditional low-input management practices and by scattered trees (Stroosnijder et al. 2008). Due to low attractiveness of olive cultivation for the younger inhabitants of the area, many plantations are abandoned or neglected (little other land management is practiced besides collecting olives). According to official data (ELSTAT), Gera's population has declined in the last decades (-37\% from 1951 to 2011 , and $-13 \%$ between 2001 and 2011), in line with the trend for the whole island. Gera is also ageing, with more than a quarter of its population older than 65. The economy of the area depends on agriculture, almost exclusively olive oil production, and to a lesser degree, on tourism and the public sector.

Fig. 3. Location of the Gera study area on Lesvos island, Greece.

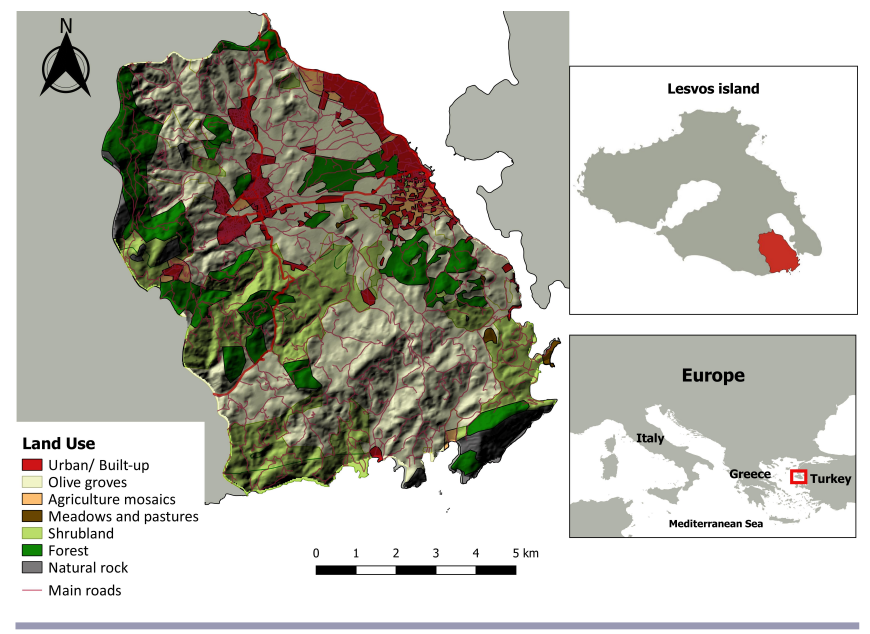

In the following subsections, we sketch different research approaches in this landscape in order to highlight similarities and differences in how each approach explains landscape changes (Table 1): (a) an analysis of historical landscape change (Case A, placed in the upper left corner of Fig. 2), (b) an investigation of decision-making processes (Case B, lower left), (c) public awareness raising (Case C, lower left), (d) evaluation of landscape services (Case D, lower left), and (e) provision of policy support (Case E, upper right). The data are taken from published (Bürgi et al. 2017, Garcia-Martin et al. 2017, Zagaria et al. 2017, Kizos et al., unpublished manuscript) and unpublished material from the European research project HERCULES (with some input from the European research project VOLANTE). The particular landscape is characterized by a high degree of biological diversity, and by a smaller degree of diversity in terms of different land covers and uses. The landscape is also quite homogenous economically and socially, with olive cultivation being the center around which the economic and social life of the area revolves. It also presents both continuity and change of its forms and functions; therefore, plurality of approaches can highlight different aspects of landscape drivers and their impacts.

\section{Historical landscape change (Case A)}

The analysis of historical landscape change addressed the following questions (Bürgi et al. 2017): How did the landscape change (if at all)? What were the dominant processes and temporal trends? What driving forces were responsible for the changes and processes observed? The data sources used were (a) historical maps (of 1961 aerial pictures and 1972 topographic maps) and remote sensing data from 2012, (b) official statistics from 1961 , 1971, 1991, 2001, and 2000, (c) 14 interviews with local informers who were old enough to have firsthand memories of land use and landscape change in the past 50 years, and (d) information from secondary literature from the 1950s until the 2010s, along with local expert knowledge. This mixed-methods approach of using quantitative and qualitative information included the following steps: first, the time line of historical changes was compiled based on secondary literature, statistical information, and expert knowledge, including important events and processes that had potential impacts on landscape change and persistence. This was complemented by a quantitative analysis of land cover and land use changes with the use of aerial pictures for 1961 and satellite images for 2012. The oral history interviews specifically addressed perceived landscape changes and related driving forces.

The analysis indicates that between 1960 and 2012, there was a dynamic relationship between olive plantations and forest areas, as olive groves were abandoned and converted to forest (though it was not always easy to distinguish between forests, wooded grasslands, shrubs, and olive plantations). At the same time, some abandoned fields that had previously turned to forest areas were cleared and converted into olive plantations again, albeit at a slower rate. Other processes, such as the conversion of olive plantations into urban areas, were of much less importance. Consequently, the proportion of land covered by olive plantations decreased from $67.8 \%$ to $60.8 \%$, and wooded grassland and shrubs increased from $7.6 \%$ to $12.8 \%$ of total land cover. Official statistics pointed to some reasons, such as population decline, ageing, and declining numbers of farms. The oral histories agreed with a "declining" view of olive cultivation, with stories of hard labor in the past and a more "alive" landscape back then.

The triangulated findings reveal that the driving forces are to some extent international, such as low prices for olive oil and the decline of the position of Lesvos as a formerly regional industrial center for olive and soap industries that served international markets. National driving forces include the (reported) lack of efficient policies, but also the Greek implementation of the Common Agricultural Policy after the 1980s, and the (reported) low level of infrastructure investments. Of greatest relevance, however, were driving forces at the local level, such as the unwillingness of young people to engage professionally with olive cultivation, even in the current economic crisis; they preferred "educational advancement" and moving away from the farming profession altogether. Structural limitations, such as labor-intensive terraces and limited accessibility due to the rugged terrain, made olive farming even less attractive. These local drivers are of course to a greater or lesser degree related to international ones.

This case illustrates that the application of pluralistic methods can be based on different conceptual models: here, the driving forces were determined by experts using the DF-C model (placing it into the upper left corner in Fig. 2), but they were also verified partially by local residents through the oral histories, which fall under the DFA-C model (so partially at least the research is also placed toward the lower left corner in Fig. 2). 
Table 1. Summary of different research approaches, changes detected, and driving forces.

\begin{tabular}{|c|c|c|c|c|c|c|}
\hline $\begin{array}{l}\text { Research appro } \\
\text { Conceptual } \\
\text { model }\end{array}$ & Research aims & Resources & Methods & Time line & Landscape changes/insights & Drivers \\
\hline \multicolumn{7}{|c|}{ Historical landscape changes (Case A) } \\
\hline $\begin{array}{l}\text { DF-C } \\
\text { model }\end{array}$ & $\begin{array}{l}\text { Describe landscape change; } \\
\text { illustrate the dominant } \\
\text { processes and temporal } \\
\text { trends; } \\
\text { synthesize the driving forces } \\
\text { that were responsible for these } \\
\text { changes }\end{array}$ & $\begin{array}{l}\text { Historical } \\
\text { maps and } \\
\text { remote } \\
\text { sensing data, } \\
\text { official } \\
\text { statistics, and } \\
\text { oral histories }\end{array}$ & $\begin{array}{l}\text { Land use/land } \\
\text { cover change } \\
\text { analysis; } \\
\text { content } \\
\text { analysis of } \\
\text { oral histories }\end{array}$ & $\begin{array}{l}\text { 1950s until } \\
\text { 2010s (with } \\
\text { older } \\
\text { insights) }\end{array}$ & $\begin{array}{l}\text { Landscape change mostly } \\
\text { through abandonment; } \\
\text { a dynamic relationship } \\
\text { between olive plantations and } \\
\text { forest areas; } \\
\text { decrease in area of olive } \\
\text { plantations; } \\
\text { conversion of olives into } \\
\text { urban areas (less important) }\end{array}$ & $\begin{array}{l}\text { International/economic (low } \\
\text { price of olive oil; less favorable } \\
\text { trade position); } \\
\text { National/economic - social } \\
\text { (reported lack of efficient } \\
\text { policies and infrastructure; rural } \\
\text { exodus); } \\
\text { Local/social - economic } \\
\text { (unwillingness of young people } \\
\text { to engage professionally in olive } \\
\text { cultivation; low profitability of } \\
\text { olive farming) }\end{array}$ \\
\hline \multicolumn{7}{|c|}{ Decision-making processes (Case B) } \\
\hline $\begin{array}{l}\text { A-C } \\
\text { model }\end{array}$ & $\begin{array}{l}\text { Describe and quantify } \\
\text { landscape changes and their } \\
\text { causes/driving forces at } \\
\text { multiple scales with the use of } \\
\text { a model to assist decision- and } \\
\text { policy-making }\end{array}$ & $\begin{array}{l}\text { Landowners' } \\
\text { interviews }\end{array}$ & $\begin{array}{l}\text { Agent-based } \\
\text { modeling }\end{array}$ & $\begin{array}{l}\text { Last decade } \\
\text { and } 25 \text { years } \\
\text { in the future }\end{array}$ & $\begin{array}{l}\text { Abandonment of olives mixed } \\
\text { with more professional and } \\
\text { intensive farming; } \\
\text { three farmer groups identified: } \\
\text { active part-timers; } \\
\text { professionals, and detached } \\
\text { farmers; polarization between } \\
\text { professionals and detached }\end{array}$ & $\begin{array}{l}\text { "Cultural drive" for preservation } \\
\text { of landscape; } \\
\text { international prices and } \\
\text { profitability of farms }\end{array}$ \\
\hline \multicolumn{7}{|c|}{ Stakeholder perspectives and landscape stewardship (Case C) } \\
\hline $\begin{array}{l}\text { DFA-C } \\
\text { and A-C } \\
\text { models }\end{array}$ & $\begin{array}{l}\text { Elicit stakeholders' } \\
\text { perceptions of landscape } \\
\text { change and values; } \\
\text { discuss principles of a } \\
\text { management plan for olive } \\
\text { cultivation; } \\
\text { witness interactions and gain } \\
\text { insights on social capital }\end{array}$ & $\begin{array}{l}\text { Three } \\
\text { workshops } \\
\text { with local } \\
\text { stakeholders }\end{array}$ & $\begin{array}{l}\text { Qualitative - } \\
\text { content } \\
\text { analysis of } \\
\text { proceedings of } \\
\text { workshops }\end{array}$ & Last decade & $\begin{array}{l}\text { Realization of abandonment } \\
\text { of olives (viewed negatively); } \\
\text { need to preserve traditional } \\
\text { management and cultural } \\
\text { practices and combine } \\
\text { traditional with "expert" } \\
\text { knowledge }\end{array}$ & $\begin{array}{l}\text { Local: widespread lack of trust } \\
\text { in institutions and cooperation in } \\
\text { general; } \\
\text { International: recognized but } \\
\text { considered less important drivers } \\
\text { than local and the national ones }\end{array}$ \\
\hline \multicolumn{7}{|c|}{ Evaluation of landscape values (Case D) } \\
\hline $\begin{array}{l}\text { A-C } \\
\text { model }\end{array}$ & $\begin{array}{l}\text { Capture local preferences, } \\
\text { perceptions, feelings, and } \\
\text { values assigned to the } \\
\text { landscape by its residents }\end{array}$ & $\begin{array}{l}\text { Public } \\
\text { participation } \\
\text { geographical } \\
\text { information } \\
\text { systems data } \\
\text { from local } \\
\text { residents }\end{array}$ & $\begin{array}{l}\text { Spatial } \\
\text { analysis }\end{array}$ & $\begin{array}{l}\text { Today and } \\
\text { last decade }\end{array}$ & $\begin{array}{l}\text { Aesthetic, spiritual, and } \\
\text { cultural linkages of locals with } \\
\text { their landscape: sea and } \\
\text { villages centers as hot spots } \\
\text { for free time and socio- } \\
\text { cultural activities }\end{array}$ & $\begin{array}{l}\text { Abandonment and urban growth } \\
\text { in the coastal zone were } \\
\text { recognized as important }\end{array}$ \\
\hline \multicolumn{7}{|c|}{ Policy support (Case E) } \\
\hline $\begin{array}{l}\text { DF-A-C } \\
\text { model }\end{array}$ & $\begin{array}{l}\text { Synthesize and meta-analyze } \\
\text { driving forces at national and } \\
\text { international levels and their } \\
\text { interrelation across scales }\end{array}$ & $\begin{array}{l}\text { Stakeholder } \\
\text { workshop and } \\
\text { expert } \\
\text { analysis }\end{array}$ & $\begin{array}{l}\text { Qualitative - } \\
\text { content } \\
\text { analysis of } \\
\text { proceedings of } \\
\text { workshop }\end{array}$ & $\begin{array}{l}\text { Last 2-3 } \\
\text { decades }\end{array}$ & $\begin{array}{l}\text { N/A (not part of the research } \\
\text { approach) }\end{array}$ & $\begin{array}{l}\text { Local: unattractiveness of } \\
\text { farming, low profits, lack of } \\
\text { adequate infrastructure, aging } \\
\text { and shrinking population; } \\
\text { National: incentives for rural and } \\
\text { tourism development; } \\
\text { fragmented laws and regulations } \\
\text { leading to unplanned urban } \\
\text { sprawl; } \\
\text { EU level: Common Agricultural } \\
\text { Policy, markets, and international } \\
\text { competition }\end{array}$ \\
\hline
\end{tabular}

\section{Decision-making processes (Case B)}

For decision-making processes that change the landscape at the local level, an agent-based modeling approach was used (Zagaria et al. 2017) to gain insights about landscape changes, their underlying causes, and their enabling and emergent driving forces at multiple scales, operationalizing the A-C model (lower-left corner in Fig. 2). An agent-based model was built to delineate future alternatives of landscape continuity and change, thereby assisting decision- and policy-making. The model was based on data on farmland characteristics, past and present management regimes, farmers' decision-making behaviors, and the farmers' future prospects (individual and sectoral), which were acquired from 100 interviews with land managers and farmers in the area who were selected at random from the available population at the time, and included both active farmers and landowners who were less or not actively farming, and were mostly aged.

Based on the collected data, three main farmer groups were identified: the active part-timer (primarily farmers who had 
multiple income activities from a wide range of sources, and extensive agricultural knowledge, and who were largely motivated to keep farming as one of their occupations and as part of their family tradition), the professional (mostly full-time farmers, who were educated and had extensive agricultural knowledge), and the detached farmer ([the predominant type in the area] who had parttime engagement in agriculture, were less educated, and had lower "cultural drive" to stay in cultivation). All groups had quite distinct rationales for their behaviors and different management decisions, and therefore, different landscape outcomes.

Results indicate that the continuation of olive cultivation in Gera is highly dependent on the number of newcomer and successor farmers (as the existing farmers' population is aged), but the preservation of the landscape and management practices that conserve it are also linked to the appreciation of the landscape for its cultural values as well as for production of olive oil. At the same time, the results show a polarization between professionals and detached farmers, indicating continuation of land abandonment. Only a combination of macrodrivers that support higher profitability on one hand and local initiatives on the other hand seems able to reverse land abandonment trends in an upcoming period of 25 years and sustain the local farming population. This combination is not very far from the findings of the historical change approach, but here the focus is on local initiatives rather than national ones, and on the farmers and landowners. The historical change analysis seems to fail to encompass the internal diversity of the actors of landscape change because it does not account for these three groups and the widely diverging trajectories that their different behaviors lead to. The agent-based modeling approach does not account for the national context of policies and other factors that have influenced landscape change in the past.

\section{Understanding stakeholder perspectives and awareness raising (Case C)}

To illustrate approaches related to landscape stewardship, three local workshops were organized to elicit stakeholders' perceptions of landscape change and values at local levels (Kizos et al., unpublished manuscript). Landscape values are process- and context-dependent, without claim to objectivity, and are formed through a structured process of communication, participation, social learning, and negotiation (Oteros-Rozas et al. 2017). Although no model was considered from the beginning, DFA-C and $\mathrm{A}-\mathrm{C}$ ones were used in the end to make sense of the results (thus placing this approach in the lower left part of Fig. 2). The first workshop was introductory, and aimed to reveal landscape issues that were important to local stakeholders. In the second workshop, these issues were further developed, along with the principles of a plan to manage olive fields. In the third workshop, this plan was discussed again, along with concrete policies and local initiatives. Stakeholders who were involved in the cultivation of olives (farmers, landowners), and administrators, citizens, and NGOs were invited to participate in these workshops. A varying number participated in each workshop (from 20 to 40 people roughly), many of whom were members of a local farmer cooperative and were keen to discuss farming practices and the future of olive farming in the area.

Stakeholders in the workshops perceived the abandonment of olives as negative and expressed the need to preserve traditional management and cultural practices by integrating traditional with "expert" knowledge on management and new technologies. A widespread lack of trust in institutions and cooperation in general was considered as a major obstacle to actions. International forces were also recognized but given less importance than local and national ones. This reflects differences in local views in relation to drivers of landscape change when discussing the present and the future instead of the past, with more weight on things that can be influenced locally.

\section{Evaluation of landscape values (Case D)}

Landscape values are becoming central in landscape management and planning, in particular, the issue of how landscapes are evaluated by different groups of landscape users (Fagerholm et al. 2012). Local opinions regarding preferences, perceptions, feelings, and values assigned to the landscape by its residents were captured using an A-C model. The participants were asked to describe landscape changes and evaluate them, but not the corresponding driving forces (placing this approach into the lower left part of Fig. 2). To this end, a PPGIS approach was designed via a web-based questionnaire with predefined location-based and nonlocation related questions (Garcia-Martin et al. 2017) for 170 respondents in a representative sample of age, gender, and residence location.

The findings from this approach reveal the aesthetic, spiritual, and cultural linkages of the locals with their landscape. Not surprisingly, in the Gera case, the sea plays a major role in these appreciations, being perceived as the most attractive place for recreation, leisure time activities, and aesthetic value. The villages are also major centers for free time and socio-cultural activities, and are highly appreciated as such, while cultivated land and "natural areas" are used and appreciated more for provisioning services and less for cultural ones. Concerning landscape changes, abandonment was recognized as important in many locations around the area, and urban growth was recognized as important in the coastal zone, while the intensification of some fields in the coastal plain was also mentioned. The importance of the sea was confirmed by asking locals, who described that even before the emergence of tourism, all households of the five inland villages moved collectively to the coast for the summer. These preferences remained unrecognized in the other research approaches used.

\section{Policy support (Case E)}

The driving forces of the changes in the landscapes of Lesvos were analyzed at the national and island levels through expert workshops with policy formulation and implementation-related stakeholders (e.g., representatives from the Regional Authorities responsible for agriculture, rural development, and spatial planning, and representatives from the Municipality of Lesvos) that operate at different levels of management, organization, and administration. The approach involved a critical synthesis and meta-analysis of driving forces at national and international levels, followed by an interpretation of these forces at the local level by involving the most important local actors. This was in line with a DF-A-C approach (placed in the upper right corner of Fig. 2). The study focused mainly on revealing the impacts of existing national- and EU-level policies, directives, and regulations. The stakeholders involved in this approach were completely different from the ones we talked with in the previous approaches, and this was reflected in the findings. 
At the local scale, the particular set of administration- and policyrelated stakeholders prioritized as the most prominent driving forces were demography (including the aging population), social unattractiveness of farming, low profits of farms, and lack of adequate infrastructure, such as roads. At the national scale, the most prominent driving forces were existing incentives for rural and tourism development and the fragmented laws and regulations, which are leading to unplanned urban sprawl at the expense of rural or forested land. At the EU level, the support of the Common Agricultural Policy was considered as very important, given the strong dependency of one of the key actor groups recognized locally-farmers - on its subsidies, and therefore was closely related to low profits and social unattractiveness of the sector. However, this reasoning does not provide a cause-effect relationship with landscape change. In fact, it could be argued that in the absence of the Common Agricultural Policy, abandonment would be far greater, and despite all its shortcomings, the Common Agricultural Policy actually helped in preserving a farming community in the area. This was missed by the participants, and in our minds clearly reflects one shortcoming of how stakeholders tend to react when confronted to establish cause-effect relationships of drivers and changes (or no changes) in the landscape. Other international-level forces, including markets and international competition, were identified as key drivers as well. Unlike previous research approaches, the local level seemed to be less important for understanding changes than were the national and international ones, and policies were given very high priority, perhaps understandably since most of the stakeholders were related to the implementation of one or more of these policies.

\section{DISCUSSION}

We applied a "portfolio approach" (Young et al. 2006) in a particular landscape - that of Gera on Lesvos island-with methods chosen to correspond to a set of research questions that addressed different aspects of human-environment interactions. The different research questions were all related to driving forces, actors, and changes in the particular landscape, but they also introduced multiple usages of the term "landscape". Landscape as a "boundary object" (Abson et al. 2014) comes to mind, as "one could frame landscape as a common area of interest which carries different meanings from different perspectives or disciplines"(Star 2010:601). This comparative approach provided multiple angles to discuss conflicts and complementarities. Therefore, we present a logical framework for ordering the portfolio of methods to be used to achieve a more holistic insight into the functioning of a landscape. We show the potential complementarities and differential insights obtained by applying such a portfolio approach for studying human-environment interactions and characterize the diversity of methods to study the driving forces of landscape change. We also sketch how different approaches are related to spatial scales, epistemological aims, and conceptual models, and compare these approaches for a particular case study. Our example illustrates the difficulties of synthesis across methods in such a portfolio approach. These arise from the different conceptual models underlying the different methods.

On the issue of complementarity, the very definitions of the different models suggest that some of these work better together with others (Hersperger et al. [2010] also discuss this point). DF-
C approaches seem to work well with DF-A-C approaches. The former appears to provide the exploration and the generation of assumptions that can then lead in DF-A-C models to the understanding of causal chains of actors and changes with particular driving forces and the identification of specific combinations of driving forces and actors that lead to change, consistent with the causal analysis framework for land use change proposed by Efroymson et al. (2016). In the same vein, A-C models work well with DFA-C models, as interactions among actors of land change, and actors' behavior and decision-making that (may) result in land change (in A-C models) can act as the basis for identifying interactions among actors and drivers of land change and provide the key to policy analysis and intervention (in DFA-C models). These are not the only possible combinations though, as the scale of the approach may determine complementarities or conflicts. In any case, where methods overlap in terms of findings, a comparison of results allows triangulation to find if results are consistent across different approaches; e.g., Cases A (historical landscape change) and B (agent-based modeling).

In our case studies, the findings suggest a high degree of complementarity for the identification of the changes from a variety of viewpoints and analysis tools. However, it is important to keep in mind that our landscape has not changed too much over the past decades (compared to other hot spots of landscape change in Europe [Kuemmerle et al. 2016]) and that those changes that occurred have been gradual. This is related to the type of changes (abandonment of the dominant livelihood, farming, which was not replaced by another economic activity that left its marks on the landscape) and the type of landscape, since olive plantations are changing slowly, and it may take decades of abandonment for them to be considered as another land use (Plieninger et al. 2011). But even here, the selection of slightly different sets of actors (e.g., farmers, nonfarmer residents, younger-older residents, culturally driven land managers, administrators) has yielded different prioritization of the driving forces of these changes. The historical analysis (DF-C model, Case A) failed to encompass the internal diversity of actors that was revealed by the agent-based approach (A-C model, Case B) and which was proven very important for understanding smallscale dynamics and processes of change. At the same time, the agent-based approach does not account for the national context of changes in detail, being based on what the agents themselves say and, as demonstrated by the opinions of stakeholders (in the A-C model, Case C), very often these seem to be blind to obvious facts and drivers when they need to establish cause-effect relationships of drivers and changes in the landscape. Similar considerations apply to the values of the landscape and its changes, which are captured directly by the PPGIS approach (Case D) and indirectly by the stewardship approach (Case C), which mainly represent the values recognized by the local stakeholders, and potentially ignore distant user's perspectives. At the same time, they allow the consideration of values that are almost completely ignored by all other approaches.

Overall, discussions among the stakeholders were not affected by the different conceptual models used. Some conflicts that emerged during the prioritization of drivers in the different approaches seem to reflect though the context and the conceptual model used. The agent-based modeling approach (Case B, DF-A-C model), 
for instance, seemed to place more weight on the local and actorbased drivers, compared to almost all other approaches that prioritize national policies and international factors. This may be related to the context of the questions asked in each approach, but it may refer to a deeper way of rationalizing causal chains of drivers and responses: when asked about broader changes, respondents and stakeholders focused on more abstract drivers, such as "the olive oil market" or "the Common Agricultural Policy," while when questioned about their choices, more personal and local factors were mentioned. Another conflict related to the conceptual model used reflects the internal diversity of local actors. Age-related factors were mentioned (younger versus older stakeholders), but the complexity revealed by the different approaches was largely lacking. This seems to be a major difference between the conceptual models and related approaches in the role that they provide to the voice of stakeholders and actors of landscape change. While this role is indirect and deducted by the analysis of quantitative data in the models that seek to describe the changes and then use experts or past knowledge to understand these changes, others focus more on what the actors say about these changes. Most often, these are not contradicting, but rather complementary approaches.

On the issue of scale, our results were mostly relevant to the case study level as a result of the particular research approaches used. Although the need to upscale agent-based modeling has been discussed in the literature (Rounsevell et al. 2014), we did not attempt it in our case. The design of the model was specific to the processes in the case study area and was not easily transferable. This has the advantage of making the method specific to the area, and the explicit representation of agent decision-making has the advantage of including the problems and behaviors of local actors, which makes the model resemble real-life situations that are easily recognizable by relevant stakeholders. However, processes at higher scales are included as (fixed) external variables. Such drivers define the context of the local processes, but are, in fact, dynamic and often the result of aggregate dynamics at lower levels. The long-term history has shown the importance of dynamic external variables and how they determine local dynamics. The limited scope of such methods in terms of scale leads to gaps in the portfolio of methods and is not easily resolved. Václavic et al. (2016) have developed a method to investigate the transferability of case study findings based on similarity of locations as determined by spatial data. However, many of the case study specificities are not easily represented in spatial data, which limits the potential of using this approach.

\section{OUTLOOK}

Land change and landscape studies are evolving fast. The need to move from a single case study and one research method approach to performing cross-site analyses has been suggested for more than a decade now and has slowly been taken up, as expressed, for example, by the rise of metastudies of the case study literature. Although this is a step in the right direction for understanding the inherent complexities of landscape change, it does not touch on another important issue: the need for a plurality of research approaches and underlying conceptualizations of human-environment interactions that can encompass the full complexity of land-use developments. The different approaches add complementary insights, a possibility to triangulation, but are also adapted to different research questions. The "added value" of complementarity/plurality of approaches compared to isolated studies is highlighted, for example, by shortcomings of a-historical scenario studies of landscape futures that have been carried out without study of past landscape dynamics and have ignored important trajectories, or by local-scale studies that ignore telecoupled driving forces, or purely global-scale studies that miss human agency at local scales and ignore the internal diversity of actors. Landscape values need to be studied together with landscape change as values also change over time, and are interlinked with the development of the physical landscape. Our case studies have delved into some of these issues of plurality and complementarity and have demonstrated how important and helpful plurality can be in landscape research, considering crossscale relations, different levels of application, and different time periods.

Typically, studies of driving forces do not provide a strong rationale for choosing a specific approach with an implicit underlying conceptual model. Rather, they take available data or preferred/familiar approaches as starting points without fully considering the implications. The examples offered here demonstrate that ignoring the underlying conceptual model of landscape change rather restricts the breadth and validity of the results derived. Our analysis provides various promising combinations and recommendations for selecting the appropriate approaches for doing landscape change research at different spatial scales. For instance, what comes out of our cases involves the combination of models of the DF-C type (e.g., historical analyses) that can provide historical "depth" and can deal with hidden and not very well understood local drivers with a larger scale approach (with DF-A-C or DF-C models) and an analysis of the decision-making process (A-C models). This would enable the understanding of local decision-making and actor diversity and then make it possible in a second phase to confront local stakeholders with the results of the historical analyses. Complementing the decision-making analysis with more information on the consequences for landscape change (in a DFAC model) could lead to stewardship options and local actions. Such an approach would move from the upper to the lower parts of Fig. 2.

In line with Seppelt et al. (2012), we promote a more systematic and structured approach for studying driving forces of landscape change to achieve high-quality scientific results that allow more robust generalization (e.g., by meta-analyses), and to improve interdisciplinary and transdisciplinary communication in all phases of a project.

Responses to this article can be read online at: http://www.ecologyandsociety.org/issues/responses. php/9910

\section{Acknowledgments:}

The research leading to these results has received funding from the European Community's Seventh Framework Program under Grant Agreement No. 603447 (Project HERCULES). 


\section{LITERATURE CITED}

Abson, D. J., H. von Wehrden, S. Baumgärtner, J. Fischer, J. Hanspach, W. Härdtle, H. Heinrichs, A. M. Klein, D. J. Lang, P. Martens, and D. Walmsley. 2014. Ecosystem services as a boundary object for sustainability. Ecological Economics 103:2937. http://dx.doi.org/10.1016/j.ecolecon.2014.04.012

Arneth, A., C. Brown, and M. D. A. Rounsevell. 2014. Global models of human decision-making for land-based mitigation and adaptation assessment. Nature Climate Change 4:550-557. http:// dx.doi.org/10.1038/nclimate2250

Bieling, C., T. Plieninger, and H. Schaich. 2013. Patterns and causes of land change: empirical results and conceptual considerations derived from a case study in the Swabian Alb, Germany. Land Use Policy 35:192-203. http://dx.doi.org/10.1016/ j.landusepol.2013.05.012

Bohnet, I. C. 2008. Assessing retrospective and prospective landscape change through the development of social profiles of landholders: a tool for improving land use planning and policy formulation. Landscape and Urban Planning 88(1):1-11. http:// dx.doi.org/10.1016/j.landurbplan.2008.07.002

Bürgi, M., C. Bieling, K. von Hackwitz, T. Kizos, J. Lieskovský, M. García Martín, S. McCarthy, M. Müller, H. Palang, T. Plieninger, and A. Printsmann. 2017. Processes and driving forces in changing cultural landscapes across Europe. Landscape Ecology 32:2097-2112. http://dx.doi.org/10.1007/s10980-017-0513$\underline{\mathrm{Z}}$

Bürgi, M., A. M. Hersperger, and N. Schneeberger. 2004. Driving forces of landscape change - current and new directions. Landscape Ecology 19:857-868. http://dx.doi.org/10.1007/ $\underline{\text { s10980-004-0245-8 }}$

Bürgi, M., D. Salzmann, and U. Gimmi. 2015. 264 years of change and persistence in an agrarian landscape: a case study from the Swiss lowlands. Landscape Ecology 30:1321-1333. http://dx.doi. org/10.1007/s10980-015-0189-1

Castella, J.-C., Tran Ngoc Trung, and S. Boissau. 2005. Participatory simulation of land-use changes in the northern mountains of Vietnam: the combined use of an agent-based model, a role-playing game, and a geographic information system. Ecology and Society 10(1):27. http://dx.doi.org/10.5751/ ES-01328-100127

Efroymson, R., K. Kline, P. H. Verburg, A. Angelsen, V. Dale, A. McBride, J. W. A. Langeveld, and G. Oladosu. 2016. A causal analysis framework for land-use change and the potential role of bioenergy. Land Use Policy 59:516-527. http://dx.doi. org/10.1016/j.landusepol.2016.09.009

Eiter, S., and K. Potthoff. 2016. Landscape changes in Norwegian mountains: increased and decreased accessibility, and their driving forces. Land Use Policy 54:235-245. http://dx.doi. org/10.1016/j.landusepol.2016.02.017

ELSTAT (Hellenic Statistical Authority). [online] URL: www. statistics.gr

Fagerholm, N., N. Käyhkö, F. Ndumbaro, and M. Khamis. 2012. Community stakeholders' knowledge in landscape assessments mapping indicators for landscape services. Ecological Indicators 18:421-433. http://dx.doi.org/10.1016/j.ecolind.2011.12.004
Garcia-Martin, M., N. Fagerholm, C. Bieling, D. Gounaridis, T. Kizos, A. Printsmann, M. Müller, J. Lieskovský, and T. Plieninger. 2017. Participatory mapping of landscape values in a PanEuropean perspective. Landscape Ecology 32:2133-2150. http:// dx.doi.org/10.1007/s10980-017-0531-X

Gennaio, M.-P., A. M. Hersperger, and M. Bürgi. 2009. Containing urban sprawl — evaluating effectiveness of urban growth boundaries set by the Swiss Land Use Plan. Land Use Policy 26:224-232. http://dx.doi.org/10.1016/j.landusepol.2008.02.010

Helfenstein, J., L. Bauer, A. Clalüna, J. Bolliger, and F. Kienast. 2014. Landscape ecology meets landscape science. Landscape Ecology 29(7):1009-1013. http://dx.doi.org/10.1007/s10980-014-0055-6

Hersperger, A. M., M.-P. Gennaio, P. H. Verburg, and M. Bürgi. 2010. Linking land change with driving forces and actors: four conceptual models. Ecology and Society 15(4):1. http://dx.doi. org/10.5751/ES-03562-150401

Jepsen, M. R., T. Kuemmerle, D. Müller, K. Erb, P. H. Verburg, H. Haberl, J. P. Vesterager, M. Andrič, M. Antrop, G. Austrheim, and I. Björn. 2015. Transitions in European land-management regimes between 1800 and 2010. Land Use Policy 49:53-64. http:// dx.doi.org/10.1016/j.landusepol.2015.07.003

Kates R. W., B. L. Turner, and W. C. Clark. 1990. The great transformation. Pages 1-17 in B. L. Turner, W. C. Clark, R. W. Kates, J. F. Richards, J. T. Mathews, and W. B. Meyer, editors. The Earth as transformed by human action. Cambridge University Press, Cambridge, Massachusetts, USA.

Kuemmerle, T., C. Levers, K. Erb, S. Estel, M. R. Jepsen, D. Müller, P. Plutzar, J. Stürck, P. J. Verkerk, P. H. Verburg, and A. Reenberg. 2016. Hotspots of land use change in Europe. Environmental Research Letters 11:064020. http://dx.doi. org/10.1088/1748-9326/11/6/064020

Levers, C., V. Butsic, P. H. Verburg, D. Müller, and T. Kuemmerle. 2016. Drivers of changes in agricultural intensity in Europe. Land Use Policy 58:380-393. http://dx.doi.org/10.1016/j.landusepol.2016.08.013

Lieskovský, J., P. Bezák, J. Špulerová, T. Lieskovský, P. Koleda, M. Dobrovodská, M. Bürgi, and U. Gimmi. 2015. The abandonment of traditional agricultural landscape in Slovakia analysis of extent and driving forces. Journal of Rural Studies 37:75-84. http://dx.doi.org/10.1016/j.jrurstud.2014.12.007

Loran, C., C. Ginzler, and M. Bürgi. 2016. Evaluating forest transition based on a multi-scale approach: forest area dynamics in Switzerland 1850-2000. Regional Environmental Change 16:1807-1818. http://dx.doi.org/10.1007/s10113-015-0911-1

Marcucci, D. J. 2000. Landscape history as a planning tool. Landscape and Urban Planning 49:67-81. http://dx.doi. org/10.1016/S0169-2046(00)00054-2

Meyfroidt, P. 2015. Approaches and terminology for causal analysis in land systems science. Journal of Land Use Science 11:501-522. http://dx.doi.org/10.1080/1747423X.2015.1117530

Oteros-Rozas, E., B. Martín-López, N. Fagerholm, C. Bieling, and T. Plieninger. 2017. Using social media photos to explore the relation between cultural ecosystem services and landscape features across five European sites. Ecological Indicators. http:// dx.doi.org/10.1016/j.ecolind.2017.02.009 
Palomo, I., B. Martín-López, P. Zorrilla-Miras, D. G. Del Amo, and C. Montes. 2013. Deliberative mapping of ecosystem services within and around Doñana National Park (SW Spain) in relation to land use change. Regional Environmental Change 14(1):237251. http://dx.doi.org/10.1007/s10113-013-0488-5

Plieninger, T., H. Draux, N. Fagerholm, C. Bieling, M. Bürgi, T. Kizos, T., Kuemmerle, J. Primdahl, and P. H. Verburg. 2016. The driving forces of landscape change in Europe: a systematic review of the evidence. Land Use Policy 57:204-214. http://dx.doi. org/10.1016/j.landusepol.2016.04.040

Plieninger, T., T. Kizos, C. Bieling, L. Le Dû-Blayo, M.-A. Budniok, M. Bürgi, C. L. Crumley, G. Girod, P. Howard, J. Kolen, T. Kuemmerle, G. Milcinski, H. Palang, K. Trommler, and P. H. Verburg. 2015. Exploring ecosystem-change and society through a landscape lens: recent progress in European landscape research. Ecology and Society 20(2):5 http://dx.doi.org/10.5751/ES-07443-200205

Plieninger, T., H. Schaich, and T. Kizos. 2011. Land-use legacies in the forest structure of silvopastoral oak woodlands in the Eastern Mediterranean. Regional Environmental Change 11:603615. http://dx.doi.org/10.1007/s10113-010-0192-7

Qviström, M. and V. Vicenzotti. 2016. Landscape research in Landscape Research: reflections on a changing field. Landscape Research 41(4):385-387. http://dx.doi.org/10.1080/01426397.20$\underline{16.1165409}$

Rounsevell, M. D. A., A. Arneth, P. Alexander, D. G. Brown, N. De Noblet-Ducoudré, E. Ellis, J. Finnigan, K. Galvin, N. Grigg, I. Harman, J. Lennox, N. Magliocca, D. Parker, B. C. O’Neill, P. H. Verburg, and O. Young. 2014. Towards decision-based global land use models for improved understanding of the Earth system. Earth Systems Dynamics 5:117-137. http://dx.doi.org/10.5194/ esd-5-117-2014

Scolozzi, R., U. Schirpke, C. Detassis, S. Abdullah, and A. Gretter. 2014. Mapping alpine landscape values and related threats as perceived by tourists. Landscape Research 40(4):451465. http://dx.doi.org/10.1080/01426397.2014.902921

Seppelt, R., B. Fath, B. Burkhard, J. L. Fisher, A. Grêt-Regamey, S. Lautenbach, P. Pert, S. Hotes, J. Spangenberg, P. H. Verburg, and A. P. E. Van Oudenhoven. 2012. Form follows function? Proposing a blueprint for ecosystem service assessments based on reviews and case studies. Ecological Indicators 21:145-154. http:// dx.doi.org/10.1016/j.ecolind.2011.09.003

Star, S. L. 2010. This is not a boundary object: reflections on the origin of a concept. Science, Technology, \& Human Values 35:601617. http://dx.doi.org/10.1177/0162243910377624

Stroosnijder, L., M. I. Mansinho, and A. M. Palese. 2008. OLIVERO: the project analysing the future of olive production systems on sloping land in the Mediterranean basin. Journal of Environmental Management 89:75-85. http://dx.doi.org/10.1016/ j.jenvman.2007.05.025

Stürck, J., C. Levers, E. H. van der Zanden, C. J. E. Schulp, P. J. Verkerk, T. Kuemmerle, J. Helming, H. Lotze-Campen, A. Tabeau, A. Popp, E. Schrammeijer, and P. H. Verburg. 2015. Simulating and delineating future land change trajectories across Europe, Regional Environmental Change 1-7. http://dx.doi. org/10.1007/s10113-015-0876-0
Thapa, G. B., and G. Rasul. 2006. Implications of changing national policies on land use in the Chittagong Hill Tracts of Bangladesh. Journal of Environmental Management 81:441-453. http://dx.doi.org/10.1016/j.jenvman.2005.12.002

Václavík, T., F. Langerwisch, M. Cotter, J. Fick, I. Häuser, S. Hotes, J. Kamp, J. Settele, H. J. Spangenberg, and R. Seppelt. 2016. Investigating potential transferability of place-based research in land system science. Environmental Research Letters 11(9):095002. http://dx.doi.org/10.1088/1748-9326/11/9/095002

Valbuena, D., A. K. Bregt, C. McAlpine, P. H. Verburg, and L. Seabrook. 2010. An agent-based approach to explore the effect of voluntary mechanisms on land use change: a case in rural Queensland, Australia. Journal of Environmental Management 91 (12):2615-2625. http://dx.doi.org/10.1016/j.jenvman.2010.07.041

Vallés-Planells, M., F. Galiana, and V. Van Eetvelde. 2014. A classification of landscape services to support local landscape planning. Ecology and Society 19(1):44. http://dx.doi. org/10.5751/ES-06251-190144

van Berkel, D. B., and P. H. Verburg. 2014. Spatial quantification and valuation of cultural ecosystem services in an agricultural landscape. Ecological Indicators 37:163-174. http://dx.doi. org/10.1016/j.ecolind.2012.06.025

van Vliet, J., H. L. F. de Groot, P. Rietveld, and P. H. Verburg. 2015a. Manifestations and underlying drivers of agricultural land use change in Europe. Landscape and Urban Planning 133:24-36. http://dx.doi.org/10.1016/j.landurbplan.2014.09.001

van Vliet, J., N. R. Magliocca, B. Büchner, E. Cook, J. R. Rey Benayas, E. C. Ellis, A. Heinimann, E. Keys, T. Ming Lee, J. Liu, O. Mertz, P. Meyfroidt, M. Moritz, C. Poeplau, B. E. Robinson, R. Seppelt, K. Seto, and P. H. Verburg. 2015b. Meta-studies in land use science: current coverage and prospects. Ambio 45:1528. http://dx.doi.org/10.1007/s13280-015-0699-8

van Zanten, B. T., P. H. Verburg, S. S. K. Scholte, and K. F. Tieskens. 2016. Using choice modeling to map aesthetic values at a landscape scale: lessons from a Dutch case study. Ecological Economics 130:221-231. http://dx.doi.org/10.1016/j.ecolecon.2016.07.008

Verburg, P. H. 2014. The representation of human-environment interactions in land change research and modelling. Pages 161177 in M. J. Manfredo, J. J. Vaske, A. Rechkemmer, and E. A. Duke, editors. Understanding society and natural resources. Springer, Netherlands. http://dx.doi.org/10.1007/978-94-017-8959-2_ 8

Verburg, P. H., N. Crossman, E. C. Ellis, A. Heinimann, P. Hostert, O. Mertz, H. Nagendra, T. Sikor, K-H. Erb, N. Golubiewski, R. Grau, M. Grove, S. Konaté, P. Meyfroidt, D. C. Parker, R. R. Chowdhury, H. Shibata, A. Thomson, and L. Zhen. 2015. Land system science and sustainable development of the earth system: a global land project perspective. Anthropocene 12:29-41. http://dx.doi.org/10.1016/j.ancene.2015.09.004

Willemen, L., L. Hein, and P. H. Verburg. 2010. Evaluating the impact of regional development policies on future landscape services. Ecological Economics 69(11):2244-2254. http://dx.doi. org/10.1016/j.ecolecon.2010.06.012

Wood, R., and J. Handley. 2001. Landscape dynamics and the management of change. Landscape Research 26:45-54. http://dx. doi.org/10.1080/01426390120024475 
Young, O. R., E. F. Lambin, F. Alcock, H. Haberl, S. I. Karlsson, W. J. McConnell, T. Myint, C. Pahl-Wostl, C. Polsky, P. Ramakrishnan, H. Schroeder, M. Scouvart, and P. H. Verburg. 2006. A portfolio approach to analyzing complex humanenvironment interactions: institutions and land change. Ecology and Society 11(2):31. http://dx.doi.org/10.5751/ES-01799-110231

Zagaria, C., C. J. E. Schulp, T. Kizos, D. Gounaridis, and P. H. Verburg. 2017. Heritage landscapes and behavioral transformations: an agent-based model for the simulation and discussion of alternative landscape futures in East Lesvos, Greece. Land Use Policy 65:26-44. http://dx.doi.org/10.1016/j.landusepol.2017.03.022 